\title{
ЭКСПЕРТНЫЙ СОВЕТ ПРИ УПРАВЛЕНИИ ПРЕЗИДЕНТА РОССИЙСКОЙ ФЕДЕРАЦИИ ПО ВОПРОСАМ ПРОТИВОДЕЙСТВИЯ КОРРУПЦИИ КАК СПЕЦИАЛИЗИРОВАННЫЙ ФЕДЕРАЛЬНЫЙ АНТИКОРРУПЦИОННЫЙ ОРГАН: ПРАВОВОЕ ПОЛОЖЕНИЕ, ОСНОВНЫЕ НАПРАВЛЕНИЯ ДЕЯТЕЛЬНОСТИ И СТРУКТУРА
}

\begin{abstract}
Аннотация: Предметом проведенного исследования является правовое регулирование деятельности специального федерального антикоррупционного органа - экспертного совета при Управлении Президента Российской Федерации по вопросам противодействия коррупции.Цель исследования - описание целей, основных задач, полномочий и структуры экспертного совета при Управлении Президента Российской Федерации по вопросам противодействия коррупции.задачи исследования:- раскрыть содержание основных задач, возлагаемых на экспертный совет при Управлении Президента Российской Федерации по вопросам противодействия коррупции;- выяснить основные полномочия экспертного совета при Управлении Президента Российской Федерации по вопросам противодействия коррупции;- предложить меры по совершенствованию правового регулирования деятельности экспертного совета при Управлении Президента Российской Федерации по вопросам противодействия коррупции. В качестве основного метода исследования использовался традиционный диалектический метод познания и основанные на нем общенаучные методы анализ, сравнение и другие. $B$ работе впервые в юридической научной литературе дается описание и объяснение правового регулирования деятельности специального федерального антикоррупционного органа - экспертного совета при Управлении Президента Российской Федерации по вопросам противодействия коррупции, описываются цели его деятельности, основные задачи, полномочия и структура, а также предлагаются некоторые меры по совершенствованию правового регулирования деятельности этого органа.

Ключевые слова: коррупция, противодействие коррупции, антикоррупционный орган, экспертный совет, антикоррупционная политика, структура совета, задачи совета, цели деятельности совета, борьба с коррупцией, экспертный орган.
\end{abstract}

$\Pi$ ротиводействие коррупции как наиболее опасному явлению сферы социального управления сложная задача, стоящая перед органами публичной власти и институтами гражданского общества. Как показывает отечественный и мировой опыт минимизировать влияние коррупции на сферу социального управления только с использованием ресурсов государства слишком затратно и малопродуктивно. В связи с этим органы публичной власти для выработки эффективных мер противодействия коррупции стали активно привлекать представителей институтов гражданского общества из различных сфер деятельности, выполняя положения федерального закона «0 противодействии коррупции». ${ }^{1}$ В качестве таких форм частно-государственного

О противодействии коррупции: Федеральный закон 25 декабря 2008 года №273-Ф3 // Собрание законодательства РФ. — 2008. - №52 (ч.1). - Ст. 6228. партнерства в сфере противодействия коррупции, предусмотренного законодательством Российской Федерации, органами публичной власти стали формироваться специализированные совещательные, консультативные и экспертные антикоррупционные органы. Основной формой такого взаимодействия выступает совместная деятельность в Советах (комиссиях) по противодействию коррупции на различных уровнях власти, состоящие как из представителей органов публичной власти, так и представителей институтов гражданского общества. Примерами создания такого антикоррупционного органа могут служить Совет при Президенте Российской Федерации по противодействию коррупции, ${ }^{2}$ Советы и ко-

О мерах по противодействию коррупции: Указ Президента Российской Федерации от 19 мая 2008 года №815 (в ред. от 14 февраля 2014 года №80) // Собрание законодательства Российской Федерации. — 2008 - №21. - Ст. 2429. 
миссии при главах субъектов Российской Федерации по противодействию коррупции, ${ }^{3}$ Советы и комиссии по противодействию коррупции при главах муниципальных образований ${ }^{4}$ в которых взаимодействие органов публичной власти с институтами гражданского общества закреплено в нормативных правовых актах, посвященных их организации и обеспечения деятельности.

Вместе с тем, в органах государственной власти субъектов Российской Федерации и органах местного самоуправления активно используются и другие формы взаимодействия органов публичной власти с институтами гражданского общества в сфере противодействия коррупции - это формирование специализированных экспертных советов. Данные экспертные органы существуют как при законодательных органах субъектов Российской Федерации, ${ }^{5}$ так и при региональных органах исполнительной власти. ${ }^{6}$ Эти антикоррупционные органы положительно себя зарекомендовали, хотя вопросы повышения эффективности их деятельности постоянно привлекают внимание

3 О создании Совета при Мэре Москвы по противодействию коррупции: Указ Мэра Москвы от 12 декабря 2008 года №101-УМ (в ред. от 15 апреля 2014 года №18-УМ) // Вестник Мэра и Правительства Москвы. - 2008. - 19 декаб.; О Совете при Президенте Республики Татарстан по противодействию коррупции: Указ Президента Республики Татарстан от 21 февраля 2011 года №УП-71 (в ред. от 18 октября 2013 года №1030) // Ведомости Государственного Совета Татарстана. - 2011. - №1-2 (II часть). - Ст.121.

4 О создании Совета при мэре города Иркутска по противодействию коррупции: Постановление мэра г. Иркутска от 2 июня 2008 года № 031-06-1163/8 (в ред. от 28 ноября 2013 года) // Ведомости органов местного самоуправления г. Иркутска. - 2008. - II квартал (часть 2). - С. 24; О Совете по противодействию коррупции города Улан-Удэ: Постановление Мэра г. Улан-Удэ от 11 сентября 2013 года // Муниципальный вестник города Улан-Удэ. - 2013. - 4 октяб.

5 Об Экспертном совете Законодательного Собрания Калужской области по противодействию коррупции: Постановление Законодательного Собрания Калужской области от 29 октября 2009 года №1441 // Весть. - 2009. - 13 нояб.; Об экспертном совете при Законодательном Собрании Челябинской области по обеспечению противодействия коррупции и экспертизе проектов нормативных правовых актов: Постановление Законодательного Собрания Челябинской области от 18 ноября 2010 года №43 // Южноуральская панорама. - 2010. - 1 декаб.

6 О создании Экспертного совета при Правительстве Пензенской области по соблюдению законодательства о противодействии коррупции при размещении государственных заказов Пензенской области: Постановление Правительства Пензенской области от 22 июня 2007 года №423-пП // Пензенские губернские ведомости. - 2007. - 12 июля. специалистов [1, с.186-189; 2, с.10-13; 3, с.50-52; 4, с.49-51; 5, с.35-38]. Кроме того, на уровне субъектов Российской Федерации в структуре органов государственной власти появляются и действуют специализированные государственные органы по противодействию коррупции.

Как показывает опыт организации противодействия коррупции использование только совещательных экспертных, консультативных и координационных антикоррупционных органов не всегда позволяет успешно формировать и реализовывать государственную политику противодействия коррупции. Именно для целей формирования и реализации национальной государственной политики противодействия коррупции в декабре 2013 года было создано Управление Президента Российской Федерации по вопросам противодействия коррупции. Основными задачами этого федерального антикоррупционного органа стали:

1) обеспечение реализации Президентом Российской Федерации его полномочий по проведению государственной политики в области противодействия коррупции;

2) государственный контроль за реализацией государственной политики в области противодействия коррупции;

3) координация деятельности органов государственной власти, иных государственных органов, органов местного самоуправления и организаций по вопросам противодействия коррупции;

4) обеспечение деятельности совещательных и консультативных органов при Президенте Российской Федерации по вопросам противодействия коррупции. ${ }^{7}$

Однако выполнение возложенных задач на Управление Президента Российской Федерации по вопросам противодействия коррупции потребовало обращения к устоявшейся практике взаимодействия в сфере противодействия коррупции с общественными объединениями, научными и учебными учреждения, экспертным сообществом. В связи с этим Президентом Российской Федерации в Национальном плане противодействия коррупции на 2014-2015 годы данному федеральному антикоррупционному органу было предложено до 1 июля 2014 года создание экспертного совета из

\footnotetext{
Об управлении Президента Российской Федерации по вопросам противодействия коррупции: Указ Президента Российской Федерации от 3 декабря 2013 года № 878 // Собрание законодательства РФ. - 2013. - №51. - Ст.
} 
числа представителей федеральных органов государственной власти, органов исполнительной власти субъектов Российской Федерации и органов местного самоуправления, общественных объединений, предпринимательских организаций, образовательных организаций высшего образования. ${ }^{8}$ Во исполнение Национального плана противодействия коррупции распоряжением Администрации Президента Российской Федерации от 16 мая 2014 года №674 «Об экспертном совете при Управлении Президента Российской Федерации по вопросам противодействия коррупции» были утверждены Положение об экспертном совете при Управлении Президента Российской Федерации по вопросам противодействия коррупции и его состав в количестве 19 человек. ${ }^{9}$

Анализ содержания этого нормативного правового акта позволяет выявить цель деятельности экспертного совета при Управлении Президента Российской Федерации по вопросам противодействия коррупции (далее по тексту экспертный совет - примечание автора), его правовое положение, функции, основные требования к членству в экспертном совете, полномочия членов экспертного совета и ряд других вопросов его деятельности.

В соответствии с Положением об экспертном совете при Управлении Президента Российской Федерации по вопросам противодействия коррупции основной целью его деятельности является обеспечение эффективного и конструктивного взаимодействия органов государственной власти Российской Федерации с общественными объединениями, научными и экспертными организациями при обсуждении вопросов выработки и реализации государственной политики в сфере противодействия коррупции.

Полномочиями по формированию, реорганизации и упразднению экспертного совета обладает Руководитель Администрации Президента Российской Федерации.

Положением об экспертном совете на него возложены следующие функции:

\footnotetext{
8 О Национальном плане противодействия коррупции на 2014-2015 годы: Указ Президента Российской Федерации от 11 апреля 2014 года №226// Собрание законодательства РФ. 2014. — №15. - Ст. 1729.

9 Об экспертном совете при Управлении Президента Российской Федерации по вопросам противодействия коррупции: распоряжение Администрации Президента Российской Федерации от 16 мая 2014 года №674 // Документ официально опубликован не был и находится в личном архиве автора.
}

a) осуществление экспертизы предложений по совершенствованию государственной политики противодействия коррупции;

б) осуществление экспертизы предложений, рассмотрение которых входит в компетенцию Управления Президента Российской Федерации по вопросам противодействия коррупции;

в) мониторинг правоприменительной практики и общественных процессов в сфере противодействия коррупции, оценка восприятия населением эффективности реализации государственной антикоррупционной политики, иначе говоря, осуществление антикоррупционного мониторинга;

г) подготовка предложений и рекомендаций по совершенствованию государственной политики и нормативно-правового регулирования в сфере противодействия коррупции;

д) обсуждение вопросов, касающихся реализации Национальной стратегии противодействия коррупции и Национального плана противодействия коррупции;

е) подготовка предложений о целесообразности использования в Российской Федерации зарубежного опыта в сфере противодействия коррупции;

ж) взаимодействие с представителями российских, зарубежных и международных организаций по направлениям деятельности экспертного совета.

В качестве членов экспертного совета могут быть несколько категорий, лиц, включенных в его состав. Во-первых, это члены экспертного совета по должности: работники Управления Президента Российской Федерации по вопросам противодействия коррупции и других самостоятельных подразделений Администрации Президента Российской Федерации, которые назначаются без внешнего согласования. Во-вторых, это члены экспертного совета, включение которых требует процедуры согласования и в их функции входит противодействие коррупции. К этой категории членов экспертного совета относятся:

- представители органов государственной власти Российской Федерации, в полномочия которых входит противодействие коррупции;

- представители экспертного сообщества, уставными задачами которых является участие в противодействии коррупции;

- $\quad$ представители деловых кругов, уставными задачами которых является участие в противодействии коррупции; 
- представители научных организаций, уставными задачами которых является участие в противодействии коррупции;

- представители средств массовой информации, уставными задачами которых является участие в противодействии коррупции;

- представители общественных объединений, уставными задачами которых является участие в противодействии коррупции.

Не зависимо от основания и порядка вхождения в состав экспертного совета все его члены осуществляют свою экспертную деятельность на общественных началах.

Основной формой деятельности экспертного совета являются заседания, проводимые по мере необходимости.

Полномочия членов экспертного совета можно разделить на общие и специальные. В число общих полномочий входят: а) внесение предложений в формирование повестки заседаний экспертного совета; б) выступление на заседаниях экспертного совета с докладами и сообщениями; в) представлять экспертные заключения и аналитические материалы по вопросам деятельности экспертного совета. Специальными полномочиями среди членов экспертного совета обладает ответственный секретарь. Он помимо общих полномочий обладает и рядом дополнительных. Во-первых, предлагает кандидатуру председательствующего на каждом заседании экспертного совета. Во-вторых, подготавливает перечень вопросов, подлежащих обсуждению на заседаниях экспертного совета. В-третьих, информирует членов экспертного совета о дате, времени и месте проведения заседаний экспертного совета и необходимости подготовки аналитических материалов. Фактически деятельность ответственного секретаря экспертного совета является организационно-управленческой и поэтому в данном качестве выступает штатный сотрудник Управления Президента Российской Федерации по вопросам противодействия коррупции. Полномочия начальника Управления Президента Российской Федерации по вопросам противодействия коррупции сводятся лишь к утверждению перечня вопросов, подлежащих обсуждению на заседаниях экспертного совета.

Для решения возложенных на экспертный совет задач ему делегированы полномочия по созданию рабочих групп и комиссий с включением в их состав внешних экспертов на основании собственного решения. Однако, в самом нормативном правовом акте не говорится о порядке принятия таких решений, их юридической силе, полномочиях и обязанностях привлекаемых внешних экспертов.

К числу важнейших составляющих любого экспертного совета является его структура и соответствия её положениям нормативного правового акта. Структура ныне действующего экспертного совета выглядит следующим образом: представители органов публичной власти 4 человека или $21 \%$; представители институтов гражданского общества 15 человек или 79\%. Среди представителей органов публичной власти в состав экспертного совета входят:

- $\quad$ сотрудник Управления Президента Российской Федерации по вопросам противодействия коррупции (В.В. Белинский),

- член Совета Федерации Федерального Собрания Российской Федерации (В.М. Бочков),

- представитель Министерства иностранных дел России (В.Е. Тарабрин)

- $\quad$ заместитель Губернатора Калужского области (Р.А. Заливацкий).

От представителей институтов гражданского общества в состав экспертного совета вошли: 4 представителя общественных организаций или $21 \%$ от общего состава экспертного совета, столько же представителей от предпринимательских организаций, 5 представителей или 26,3\% от учреждений высшего образования и 2 представителя средств массовой информации или 10,5\% от общего количества экспертов.

Проведенный нами анализ правового регулирования деятельности экспертного совета при Управлении Президента Российской Федерации по вопросам противодействия коррупции позволяет нам констатировать, о том, что его правовое положение соответствует общепринятым правилам правового регулирования деятельности указанных совещательных антикоррупционных органов. В качестве основного достоинства можно отметить очень высокое представительство институтов гражданского общества в его структуре, что позволяет охватить широкий спектр обсуждения вопросов противодействия коррупции в различных социальных группах. Однако, невзирая на важность и качество правового регулирования деятельности экспертного совета необходимо принять меры по совершенствованию Положения о нем, дополнительно определив статус привлекаемых внешних экспертов и юридический статус решений принимаемых этим федеральным антикоррупционным органом. 


\section{Библиография:}

1. Гребенюк Р.А. Указ Президента РФ о совете по борьбе с коррупцией: за и против // Труды юридического факультета Ставропольского государственного университета. - Вып. 5. - Ставрополь, 2004. C. 186-189.

2. Кабанов П.А. Республиканский совет по реализации антикоррупционной политики как субъект противодействия коррупции в Республике Татарстан // Следователь. - 2008. - № 1. - С. 10-13.

3. Кабанов П.А. Совет при Президенте Российской Федерации по борьбе с коррупцией: осознанная необходимость или предвыборный шаг? // Следователь. - 2004. — № 1. - С. 50-52.

4. Куракин А.В. Совет при Президенте Российской Федерации по борьбе с корупцией: структура, задачи и функции // Современное право. — 2004. — № 7. — С. 49-51.

5. Сабитова Э.Н. Правовые и организационные основы деятельности специализированных совещательных, координационных, межведомственных, экспертных советов и комиссий по противодействию коррупции субъектов Российской Федерации // Взаимодействие институтов гражданского общества и органов местного самоуправления в сфере противодействия коррупции: материалы Всероссийского межвузовского круглого стола г. Нижнекамск, 23 декабря 2011 г. / под ред. П.А. Кабанова, О.Д. Агапова. - Казань: Познание, 2012. - С. 35-38.

6. Кабанов П.А. Президиум Совета при Президенте Российской Федерации и образуемые им рабочие органы как высшие федеральные специализированные антикоррупционные учреждения: вопросы повышения качества правового регулирования и эффективности их деятельности // NB: Административное право и практика администрирования. - 2013. - 2. - C. 91-104. DOI: 10.7256/23069945.2013.2.370. URL: http://www.e-notabene.ru/al/article_370.html

\section{References:}

1. Grebenyuk R.A. Ukaz Prezidenta RF o sovete po bor'be s korruptsiei: za i protiv // Trudy yuridicheskogo fakul'teta Stavropol'skogo gosudarstvennogo universiteta. - Vyp. 5. - Stavropol', 2004. - S. 186-189.

2. Kabanov P.A. Respublikanskii sovet po realizatsii antikorruptsionnoi politiki kak sub"ekt protivodeistviya korruptsii v Respublike Tatarstan // Sledovatel'. — 2008. — № 1. — S.10-13.

3. Kabanov P.A. Sovet pri Prezidente Rossiiskoi Federatsii po bor'be s korruptsiei: osoznannaya neobkhodimost' ili predvybornyi shag? // Sledovatel'. — 2004. — № 1. - S. 50-52.

4. Kurakin A.V. Sovet pri Prezidente Rossiiskoi Federatsii po bor'be s koruptsiei: struktura, zadachi i funktsii // Sovremennoe pravo. — 2004. — № 7. — S. 49-51.

5. Sabitova E.N. Pravovye i organizatsionnye osnovy deyatel'nosti spetsializirovannykh soveshchatel'nykh, koordinatsionnykh, mezhvedomstvennykh, ekspertnykh sovetov i komissii po protivodeistviyu korruptsii sub"ektov Rossiiskoi Federatsii // Vzaimodeistvie institutov grazhdanskogo obshchestva i organov mestnogo samoupravleniya $\mathrm{v}$ sfere protivodeistviya korruptsii: materialy Vserossiiskogo mezhvuzovskogo kruglogo stola g. Nizhnekamsk, 23 dekabrya 2011 g. / pod red. P.A. Kabanova, O.D. Agapova. - Kazan': Poznanie, 2012. - S. 35-38.

6. Kabanov P.A. Prezidium Soveta pri Prezidente Rossiiskoi Federatsii i obrazuemye im rabochie organy kak vysshie federal'nye spetsializirovannye antikorruptsionnye uchrezhdeniya: voprosy povysheniya kachestva pravovogo regulirovaniya i effektivnosti ikh deyatel'nosti // NB: Administrativnoe pravo i praktika administrirovaniya. - 2013. - 2. - C. 91-104. DOI: 10.7256/2306-9945.2013.2.370. URL: http://www.enotabene.ru/al/article_370.html 